\title{
Intravaginal torsion of undescended testes
}

\author{
Filipe La Fuente Carvalho (1) ${ }^{1}$ Ish Talati, ${ }^{2}$ Aaron Krill ${ }^{3}$
}

'Department of Urology, MedStar Georgetown University Hospital, Washington, District of Columbia, USA

${ }^{2}$ Georgetown University School of Medicine, Washington, District of Columbia, USA ${ }^{3}$ Division of Urology, Children's National Medical Center, Washington, District of Columbia, USA

Correspondence to Dr Filipe La Fuente Carvalho; filipe.decarvalho@gunet. georgetown.edu

Accepted 13 October 2019

\section{DESCRIPTION}

A 5-month-old male infant status post routine neonatal circumcision with known left inguinal testis presented to the emergency room with swelling and redness in the left inguinal region for over 24 hours. Physical examination revealed an indurated inguinal bulge with associated erythema (figure 1). The right testis was normal, and the left hemiscrotum was empty. Scrotal ultrasound revealed an enlarged, heterogeneous testis without Doppler flow. $\mathrm{He}$ was emergently taken to the operating room for inguinal exploration which confirmed an intravaginal torsion, non-viable testis (figure 2) and closed inguinal canal. Left orchiectomy and right scrotal orchiopexy were performed without complication. The final pathology revealed an infarcted and haemorrhagic testicle and epididymis.

Undescended testes (UDTs) affect up to $8 \%$ of full term, but $33 \%$ of premature male neonates, as the testis enters the inguinal canal after 28 weeks' gestation. ${ }^{1-3}$ Insulin-like 3 and its receptor, relaxin family peptide receptors (RXFP), may play a role in the transabdominal migration as their loss results in UDTs in animal models. ${ }^{4}$ Seventy per cent of UDTs are palpable in the upper scrotum or low inguinal canal. Of non-palpable UDTs, 55\%, 35\% and $15 \%$ are in the abdomen, inguinal canal or absent, respectively. ${ }^{5}$ A patient with solitary UDT and hypospadias requires evaluation for a disorder of sexual development, but in patients without penile anomalies, UDT treatment can be delayed until 6 months of age. ${ }^{6}$ The scrotal location supports

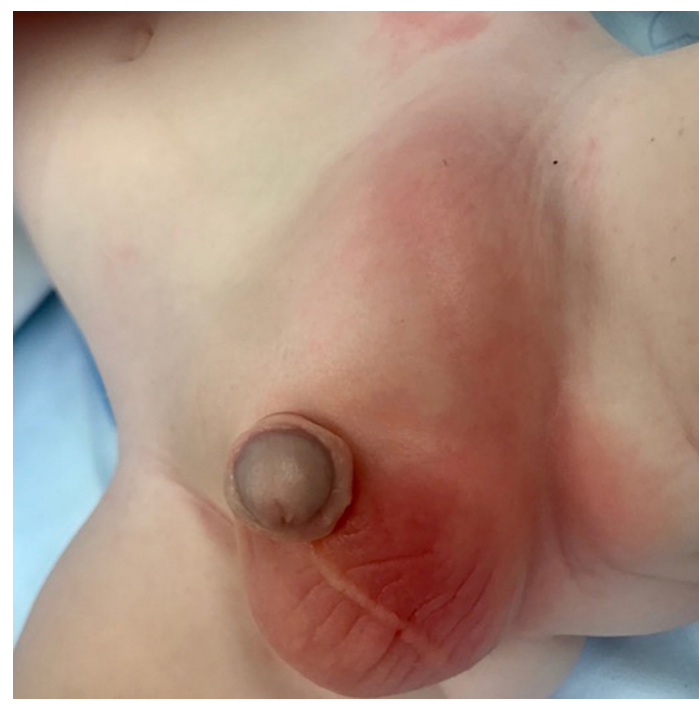

Figure 1 Physical examination of the patient in the emergency room revealed an indurated left inguinal bulge with associated erythema.

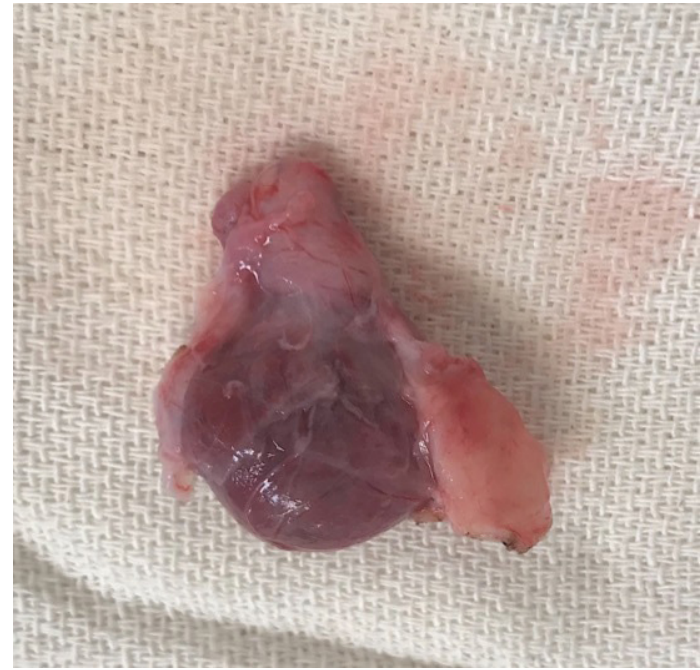

Figure 2 Gross pathology of the left inguinal testis showing necrosis.

testicular function such that UDTs are associated with subfertility and germ cell malignancies. ${ }^{1-3}$

The aetiology of torsion in UDTs is unknown, but may be related to abnormal cremasteric muscle contractions or gubernacular attachments. Intravaginal torsion (torsion of the testicle within the tunica vaginalis) is more common in infants over 30 days of age and those with UDTs, compared with extravaginal torsion (torsion of the testis and tunica vaginalis as a unit) which is more common in neonates. ${ }^{7-9}$ While the incidence of torsion in UDTs is unknown, it is higher than the incidence in orthotopic testes. ${ }^{2}{ }^{10}$ As demonstrated in this case, findings include abdominal and groin pain with ipsilateral inguinal swelling and erythema. Infants may present with inconsolable crying ${ }^{6}$ and should be evaluated emergently with a differential diagnosis including incarcerated inguinal hernia, intussusception and viral gastroenteritis. ${ }^{12}$

Doppler ultrasound has a sensitivity of $77.8 \%$ and specificity of $90 \%$ for diagnosing testicular torsion. However, its accuracy in UDTs decreases due to difficulty evaluating the inguinal canal. ${ }^{1}$ As such, in suggestive cases with acute pain, inguinal swelling and empty ipsilateral hemiscrotum, surgical exploration should not be delayed. Surgery within 6 hours of torsion is generally successful, however due to often delayed diagnosis, the success rate in UDT torsion is below $40 \% .^{211}$ While the specific risk of contralateral torsion in UDTs is unknown, contralateral orchiopexy is recommended due to the risk of metachronous torsion and subsequent anorchia, in addition to the low morbidity of the procedure. $^{7911}$ 
Our case illustrates the typical presentation of torsion of UDTs. As orchiopexy is routinely delayed until 6 months, emergency physicians, paediatricians and parents must be aware that torsion of the UDT is possible in the interim. Parents and paediatricians should be aware that changes in the inguinal region associated with UDT require emergent evaluation.

\section{Learning points}

Acute inguinal pain or swelling in the setting of an empty ipsilateral hemiscrotum or history of undescended testis requires urgent surgical evaluation.

- Torsion of an undescended testis is associated with poor salvage rates due to delay in diagnosis.

- Parents and clinicians should be aware that torsion of an undescended testis can occur while awaiting spontaneous descent or surgical correction.

Contributors FLFC and AK had full access to all the data in the manuscript and take responsibility for the integrity of the data and the accuracy of the events. IT drafted the manuscript, provided technical and material support.

Funding The authors have not declared a specific grant for this research from any funding agency in the public, commercial or not-for-profit sectors.

Competing interests None declared.

Patient consent for publication Parental/guardian consent obtained.
Provenance and peer review Not commissioned; externally peer reviewed.

\section{ORCID iD}

Filipe La Fuente Carvalho http://orcid.org/0000-0003-2378-6512

\section{REFERENCES}

1 Moore CP, Marr JK, Huang CJ. Cryptorchid testicular torsion.. Pediatr Emerg Care 2011;27:121-3.

2 Pogorelić Z, Mrklić I, Jurić I, et al. Testicular torsion in the inguinal canal in children. J Pediatr Urol 2013;9:793-7.

3 Barthold JS. Abnormalities of the Testis and Scrotum and their Surgical Management. In: McDougal WS, Kavoussi LR, NOvick AC, eds. Campbell Walsh urology. 10th ed. Philadelphia, PA: WB Saunders, 2012: 642-5.

4 Kalfa N, Gaspari L, Ollivier M, et al. Molecular genetics of hypospadias and cryptorchidism recent developments. Clin Genet 2019;95:122-31.

5 Denes FT, Saito FJ, Silva FA, et al. Laparoscopic diagnosis and treatment of nonpalpable testis. Int Braz J Urol 2008;34:329-35.

6 Radmayr C, Dogan HS, Hoebeke P, et al. Management of undescended testes: European association of Urology/European Society for paediatric urology guidelines. $J$ Pediatr Urol 2016;12:335-43.

7 Monteilh C, Calixte R, Burjonrappa S. Controversies in the management of neonatal testicular torsion: a meta-analysis. J Pediatr Surg 2019;54:815-9.

8 Mano R, Livne PM, Nevo A, et al. Testicular torsion in the first year of lifecharacteristics and treatment outcome. Urology 2013;82:1132-7.

9 Bordin G, Parolini F, Morandi A, et al. Intravaginal testicular torsion in newborns. to fix or not to fix the contralateral testis? Pediatr Med Chir 2013;35:225-7.

10 Zilberman D, Inbar Y, Heyman Z, et al. Torsion of the cryptorchid testis--can it be salvaged? J Urol 2006;175:2287-9.

11 Naouar S, Braiek S, El Kamel R. Testicular torsion in undescended testis: a persistent challenge. Asian J Urol 2017;4:111-5.

Copyright 2019 BMJ Publishing Group. All rights reserved. For permission to reuse any of this content visit

https://www.bmj.com/company/products-services/rights-and-licensing/permissions/

BMJ Case Report Fellows may re-use this article for personal use and teaching without any further permission.

Become a Fellow of BMJ Case Reports today and you can:

- Submit as many cases as you like

- Enjoy fast sympathetic peer review and rapid publication of accepted articles

- Access all the published articles

- Re-use any of the published material for personal use and teaching without further permission

\section{Customer Service}

If you have any further queries about your subscription, please contact our customer services team on +44 (0) 2071111105 or via email at support@bmj.com.

Visit casereports.bmj.com for more articles like this and to become a Fellow 